Фролов В. С. к.військ.н., снс;

Саганюк Ф. В. к.ю.н., доцент

Центр воєнно-стратегічних досліджень Національного університету оборони України імені Івана Черняховського, Київ

\title{
Стратегія переходу в умовах гібридної війни до нового формату стратегічного керівництва сектором безпеки i оборони України
}

Резюме. Стаття присвячена проблемі переходу сектора безпеки і оборони України та стратегічного керівництва силами оборони до нового формату функціонування й протидії російській агресії.

Ключові слова: агресор, гібридна війна, сектор безпеки і оборони, сили оборони, стратегічне керівництво.

Постановка проблеми. Збігає трирічний час, як Росія розв'язала безпрецедентну гібридну війну проти України, окупувавши Крим та частину Донбасу. Нині активна оборона України від російського агресора залишається найбільш актуальною проблемою сьогодення 3 метою примушення його до припинення воєнних дій шляхом проведення спільних операцій сил оборони у поєднанні 3 організацією активного опору [1, п. 20, 21].

Для цього нещодавно в Україні проголошено про необхідність переходу до нового формату протидії агресору. Розробляється законопроект, яким передбачається визначити комплекс силових й дипломатичних кроків, що мають забезпечити звільнення окупованих територій від агресора та внормувати нові підходи щодо формування стратегічного керівництва Збройними Силами України й іншими складовими сил оборони та визначити нові засади їх застосування проти агресора [2].

Аналіз останніх досліджень i публікацій. Проблема переходу до нового формату протидії агресору $\epsilon$ зовсім новою. В сучасній літературі вона ще недостатньо досліджена i потребує більш детального вивчення та обговорення.

Нерозв' язаними сучасними проблемами, визначеними Стратегічним оборонним бюлетенем України, введеним в дію Указом Президента України від 6 червня 2016 року № 240/2016, залишається відсутність єдиного стратегічного керівництва силами оборони, яке здійснювалося б відповідно до принципів та стандартів, прийнятих державами-членами НАТО, чіткого розподілу відповідальності за формування та застосування сил оборони, що негативно позначається на ефективності стратегічного керівництва сектором безпеки і оборони України.

Метою статті $\epsilon$ пошук та обгрунтування ефективних стратегічних підходів щодо розв'язання проблем в секторі безпеки i оборони України, переходу Збройних Сил України та інших складових сил безпеки i оборони та стратегічного керівництва ними до нового формату протидії агресору.

Виклад основного матеріалу. Гібридна війна, яку розв'язала і досі веде проти України Російська Федерація (РФ), на погляд фахівців, $\epsilon$ довгостроковим фактором впливу на українську політичну, економічну, воєнну, інформаційну, соціальну та інші сфери життєдіяльності держави. Внаслідок гібридних дій РФ деформувала систему глобальної й регіональної безпеки та міжнародного права. Майже усі ii міжнародні гарантії безпеки для України, зокрема в рамках Будапештського меморандуму, виявились знехтуваними. Натомість РФ застосувала проти України концепцію гібридної війни, яка зі структурно-функціональної точки зору - за формою є гібридною, а за змістом - асиметричною. Велике значення у ній надається не величі збройних сил, а їхній спроможності здійснювати швидкі й 
ефективні операції на будь-якому театрі воєнних дій, зокрема, у нетрадиційних умовах “комплексного застосування політичних, економічних, інформаційних та інших невоєнних заходів", що реалізуються агресором 3 опорою на військову силу. Це підтвердив і начальник Генерального штабу збройних сил Росії генерал армії В. Герасимов у своєму виступі на підсумковій конференції Академії військових наук РФ ще 27 лютого 2016 року. При цьому він наголосив на необхідності підвищення ролі невоєнних методів тиску 3 боку Росії, у першу чергу через політичний, економічний та гуманітарний елементи. Інформаційне протиборство та стрімкий ріст інформаційного впливу ним визнано як наріжний засіб діяльності ЗС РФ на всіх зазначених напрямах [3].

3 наведеного витікає, що сучасне протиборство України проти російського агресора теж доцільно згуртувати і вести саме на всіх зазначених чотирьох напрямах, що обгрунтовується авторами $\mathrm{y}[4]$.

Перший напрям - відстоювання політичних, економічних, енергетичних, транспортних та інших національних інтересів держави у геоекономічному просторі мирними методами, використовуючи дипломатичні представництва, міжнародні організації, двох або багатосторонні міждержавні договори тощо.

Другий - відстоювання національних інтересів України в інформаційному та кіберпросторі.

Третій - посилення внутрішньої безпеки держави, основу якої складають боротьба із втручанням спецслужб інших держав у внутрішні справи; протидія тероризму, бандитизму, сепаратизму; боротьба із шпіонажем та розвідкою іноземних держав; моніторинг та сприяння стабільності міжнаціональних, міжконфесійних, міжетнічних та інших сфер національних взаємовідносин тощо.

Четвертий - збройна боротьба із поетапним нарощуванням угруповань військ для розширення контролю на окупованих противником територіях.

Важливим елементом сектора безпеки і оборони України у цій протидії має бути ефективна система стратегічного керівництва.
Аналіз цих проблем й досвід ведення бойових дій в АТО підтверджують недостатню готовність складових сектора безпеки і оборони України, зокрема, його стратегічного керівництва адекватно протидіяти російській агресії в умовах ведення проти України неоголошеної гібридної війни.

Помилкове не бачення в минулому загрози війни 3 боку РФ зневілювало необхідність створення оперативностратегічних та мобільних оперативнотактичних угруповань військ, що стало основним аргументом для організації оборони України за територіальним принципом, силами бригад у складі Оперативних Командувань (ОК). Структура Збройних Сил України, основу якої складають їх види та ОК, формувалась лише для організації бойових дій $\mathrm{y}$ прикордонних воєнних конфліктах у взаємодії з підрозділами ДПС та МВС (див. puc.1). А територія держави розподілялась між ОК, на які покладалась повна відповідальність за територіальну цілісність держави, включаючи й повітряну оборону.

Об'єднане Оперативне Командування (ООК), яке створювалось для управління міжвидовим оперативно-стратегічним угрупованням військ (сил) Збройних Сил ніби 3 наближенням до стандартів НАТО, було розформоване, на наш погляд, помилково.

ОК тоді створювались як тимчасові органи військового управління 3 метою організованого розформування військових округів, перетворення армій у армійські корпуси, а дивізій - у бригади та для організованої передачі озброєння й майна на склади ЗС України; військових містечок - органам місцевого самоврядування. У подальшому планувалось реформувати ОК у Територіальні командування для управління територіальною обороною та мобілізацією в межах зон відповідальності.

Досвід ведення бойових дій в АТО показує, що командування та штаби ОК неспроможні здійснювати планування, підготовку й управління угрупованнями військ, а зони відповідальності Повітряних Командувань - забезпечити єдине керівництво системою ППО в межах зони ведення АТО та протидіяти реальним загрозам порушень повітряного простору 3 боку Росії. 


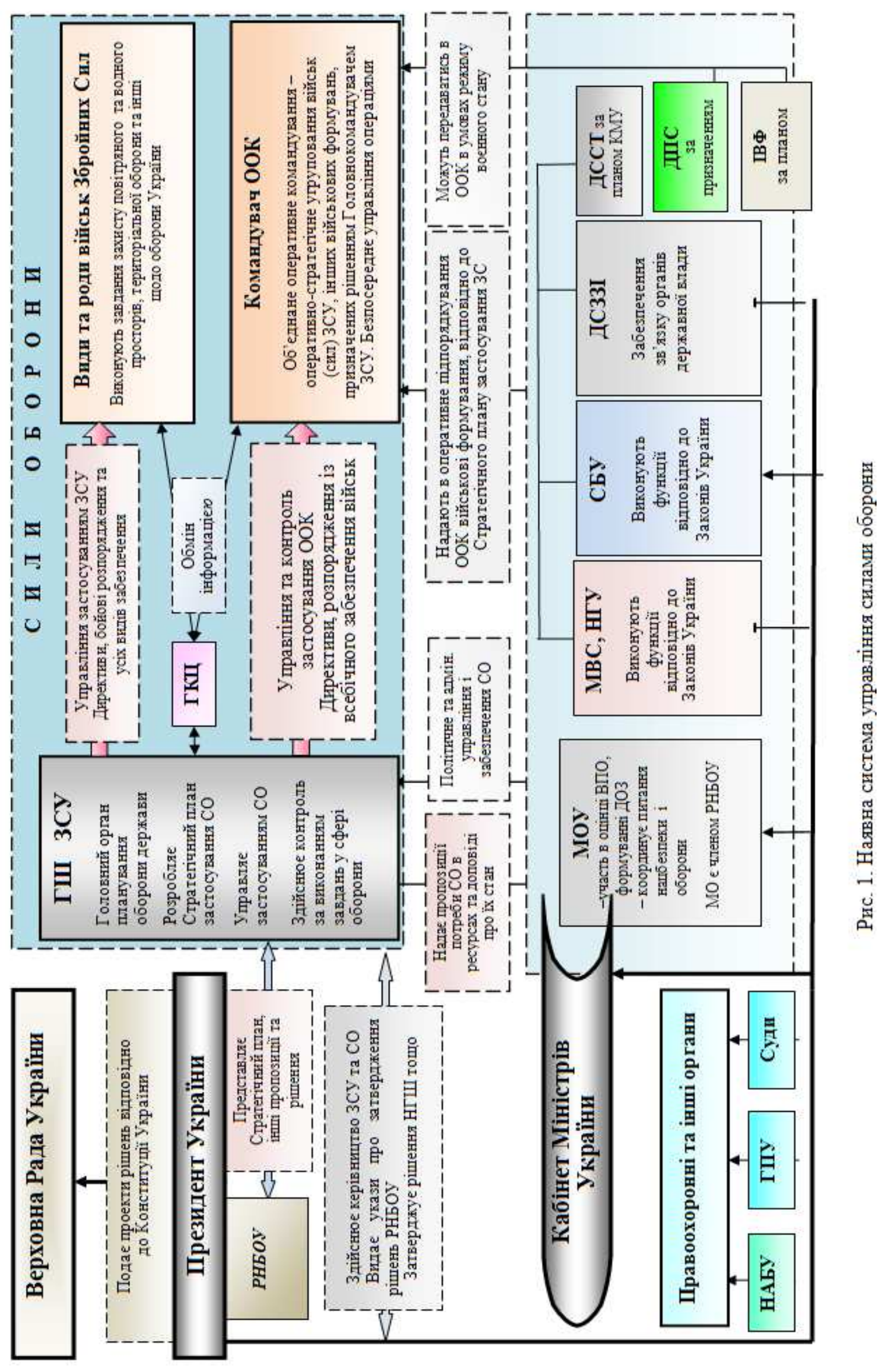


При цьому необхідно враховувати й те, що стратегічне керівництво агресивними діями Росії у гібридній війні проти України максимально сконцентроване на усіх напрямах виключно в руках Президента РФ.

Постійне нарощування Російською Федерацією потужних угруповань військ впритул кордонів України зараз, про що наголошує i керівництво МО України [5], вимагає формування адекватного оперативностратегічного угруповання військ (ООК) у складі саме армійських корпусів та перегляду зон відповідальності повітряних командувань за оборону повітряного простору України.

Завдання України у цих умовах полягає не у створені нового формату системи стратегічного керівництва силами оборони, тобто стратегічного військового управління, а у створенні нового формату єдиної системи керівництва сектором безпеки $i$ оборони Украӥни в цілому.

Розглядаючи шляхи розбудови нового формату стратегічного керівництва сектором безпеки i оборони в сучасних безпекових умовах, необхідно, на наш погляд, у першу чергу, розмежувати ці два поняття "стратегічне керівництво сектором безпеки i оборони” та "стратегічне військове управління силами оборони”. В законодавстві України й у працях відомих науковців вони не конкретизовані i не розмежовані. Однак, більш детальний аналіз цих понять та функцій складових сектора безпеки i оборони, визначених Конституцією України, іншими законодавчими та нормативно-правовими актами й сучасними концептуальними документами, дає можливість сформувати наступний їх перелік.

\section{Функції стратегічного керівництва сектора безпеки і оборони:}

формування та забезпечення реалізації єдиної державної політики у сфері національної безпеки і оборони;

збір та вивчення воєнно-політичної обстановки, аналіз стану і тенденцій розвитку зовнішньо-та внутрішньополітичної ситуації, визначення на цій основі стратегії та пріоритетних напрямів забезпечення національної безпеки і оборони;

комплексна оцінка та прогноз потенційних і реальних загроз державному, економічному, суспільному, оборонному, інформаційному, екологічному та іншим видам і об' єктам безпеки України;

планування, організація і контроль за здійсненням заходів політичного, економічного, воєнного, соціального, науково- технічного та іншого характеру, адекватним цим загрозам;

формування Державного оборонного замовлення та проекту Закону України "Про Державний бюджет України"; фінансування витрат на національну безпеку і оборону;

оголошення стану війни, введення режиму воєнного стану, об'явлення мобілізації та рішення на введення в дію мобілізаційного плану держави;

розгляд та вирішення інших актуальних питань національної безпеки i оборони держави.

\section{Функцї стратегічного військового управління:}

аналіз та оцінка воєнно-стратегічної обстановки;

прогноз тенденцій розвитку форм та способів воєнних дій й засобів збройної боротьби, обгрунтування напрямів розвитку Збройних Сил та інших складових сил оборони; стратегічне планування ї застосування для оборони держави;

визначення потреб у особовому складі, озброєнні, військовій техніці, матеріальнотехнічних, енергетичних, фінансових, інформаційних, продовольчих, земельних й водних ресурсах, комунікаціях, фондах та майні, необхідних для належного виконання визначених їм завдань та контроль за повнотою і якістю їх забезпечення;

планування та контроль у особливий період за військовими перевезеннями усіх видів;

керівництво у сфері оборони та забезпечення у визначених законом межах громадського порядку в Україні або окремих іiі місцевостях, де введено воєнний стан;

управління стратегічним розгортанням Збройних Сил та іншими визначеними складовими сил оборони;

ведення розвідувальної та інформаційноаналітичної діяльності в інтересах підтримання у готовності до бойового застосування Збройних Сил та інших складових сил оборони; реалізація інших повноважень, визначених законами та іншими нормативноправовими актами України.

Об'єктом стратегічного військового управління тут мають бути сили оборони як складова сектора безпеки і оборони України.

Враховуючи зазначені елементи та вимоги Стратегічного оборонного бюлетеня України від 2016 року можна окреслити новий формат системи стратегічного керівництва силами оборони зразка 2018, а потім 2020 рр., наближаючись поступово до переходу його до 
формату, передбаченого стандартами НАТО. При цьому потрібно враховувати те, що однією із основних умов створення такої системи оборони за принципами та стандартами НАТО, має бути відновлення ООК, як органу управління оперативностратегічним угрупованням військ та армійських корпусів - оперативно-тактичних об'єднань.

Головнокомандувач Збройних Сил України, як найвища військова посадова особа, має очолювати стратегічне військове управління силами оборони усього сектора безпеки i оборони України. Він має підпорядковуватися Президенту України та Міністру оборони України і бути їх радником з військових питань.

За світовим досвідом ведення війн та воєнних конфліктів, у тому числі у форматі АТО в Україні, для безпосереднього управління силами оборони доцільно створити Головний штаб Головнокомандувача Збройними Силами.

У державах-членах НАТО базову основу організації військового управління армій складає Об'єднаний штаб (Joint staff). Адміністративні та оперативні стандарти НАТО можуть застосовуватись лише для структур Об'єднаного штабу, а не для структур інших штабів.

Головнокомандувачу Збройних Сил України мають бути безпосередньо підпорядковані Командувач ООК, Командувачі видами ЗСУ, ВДВ та ССО. Командувач ООК через ООШ повинен здійснювати управління угрупованням Збройних Сил, що виділятимуться до складу військ НАТО та оперативно-стратегічним угрупованням військ, що призначатимуться для оборони держави.

Аналіз характеру воєнних загроз, пов'язаних тісно між собою в усіх сферах функціонування держави, новітніх методів підготовки й ведення гібридних війн, а також досвід ведення бойових дій в АТО підтверджує потребу інтеграції управлінських зусиль керівництва держави в усіх сферах безпеки і оборони України в єдину систему стратегічного керівниитва сектором безпеки $i$ оборони нового формату відповідно до сучасних умов i потреб. Такий підхід відповідатиме одному із основних базових принципів НАТО щодо чіткого розподілу та делегування відповідальності під час формування й реалізації рішень в усій системі управління - від воєнно-політичного керівництва до окремого підрозділу. Варіант формату наведено на рис. 2.

Враховуючи досвід держав-членів НАТО та відповідно до вимог Конституції України, Законів України "Про оборону України", "Про основи національної безпеки України", основним консолідуючим базовим органом стратегічного керівництва сектором безпеки і оборони України може бути Рада національної безпеки $i$ оборони Украӥни, однак за умови уточнення у законодавчому порядку ії функцій та відповідного реформування організаційноштатної структури. Відповідно до ст. 107 Конституції України основними функціями РНБО у цій сфері можуть бути:

оцінка воєнно-політичної, економічної, інформаційної, криміногенної й іншої обстановки та iï впливу на безпеку і оборону держави;

визначення загроз національній безпеці в усіх сферах життєдіяльності держави;

обгрунтування стратегічних цілей, мети та основних напрямів і завдань в усіх сферах функціонування держави щодо протидії гібридній агресії противника;

формування комплексних програм протидії агресору на кожному етапі підготовки та ведення гібридної війни противником;

розроблення проектів необхідних законодавчих та інших нормативно-правових актів щодо оборони держави й підготовка їх для подання встановленим порядком до Верховної Ради України;

координація та контроль органів виконавчої влади, а в особливий період i приватного бізнесу, у сфері національної безпеки і оборони тощо.

У цьому контексті на наш погляд, доцільно сформувати й структуру ситуаційного центру РНБО, наприклад як варіант, у складі фінансово-економічної групи від Кабінету Міністрів України; інформаційну групу від Міністерства інформації; групу внутрішньої безпеки від силових структур та правоохоронних органів i групу від Міністерства оборони.

У загрозливий період (з початком агресіі) для посилення ситуаційного центру доцільно формувати оперативні групи (на постійній основі) під керівництвом віце-прем'єра та заступників міністрів (відомств). 


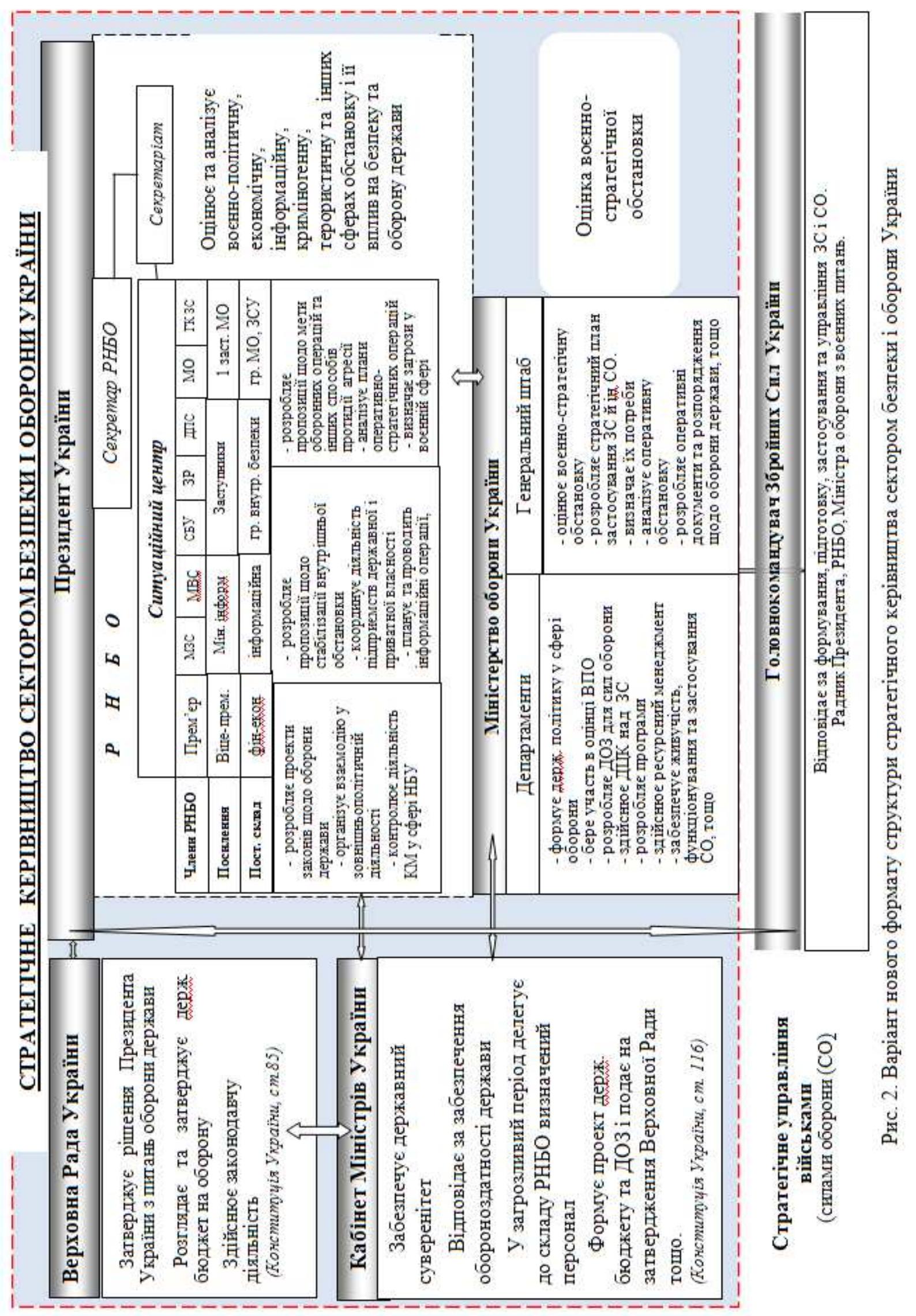


Висновок. Наведений аналіз зазначених вище проблем та наявного досвіду дає підстави стверджувати, що стратегічне керівництво сектором безпеки i оборони України - це комплекс політичних, правових, економічних, воєнних, наукових, інформаційних та інших заходів держави щодо виявлення та визначення ефективних методів нейтралізації загроз національним інтересам держави на усіх зазначених вище чотирьох напрямах.

Напрямок подальших досліджень. Для розв'язання окресленої проблеми необхідно вдосконалити чинне законодавство, закріпити і визначити у ньому сектор безпеки і оборони як складову підсистему національної безпеки і оборони держави, його керівництво, склад та структуру (новий формат), включаючи керівництво та механізми функціонування, уточнивши їх завдання й функції, порядок взаємодії та застосування у передбачених законом випадках, порядок стратегічного планування розвитку спроможностей його складових для забезпечення більш ефективного виконання покладених на них завдань щодо оборони держави від агресора на всіх зазначених вище напрямах.

\section{СПИСОК ВИКОРИСТАНОЇ ЛІТЕРАТУРИ}

1. Воєнна доктрина України / Затверджена Указом Президента України від 24 вересня 2015 року № 555/2015.

2. Замість АТО: деталі законопроекта РНБО [Електронний ресурс]. - Режим доступу: http://news.liga.net/news/politics/14770888-

smi_obyasnili_chto_stoit_za_smenoy_nazvaniya_ ato.htm

3. "Гибридная война" как ключевой инструмент российской геостратегии реванша [Електронний pecypc]. - Режим доступу: http:// www. stopfake. org/gibridnaya-vojna-kak-klyuchevojinstrument-rossijskoj-geostrategii-revansha/

4. Фролов В.С. Деякі підходи щодо стратегії протистояння та протидії агресору / В.С.Фролов, Ф.В. Саганюк, М.М. Лобко // Збірник наукових праць ЦВСД НУОУ. - 2017. - № 1. - С. 5-11.

5. На півдні і сході Україну оточили 60 тисяч військових РФ - Міноборони // Українська правда. - 2017. - 4 липня

Стаття надійшла до редакції 07.07.2017

Фролов В. С., к.воен.н., с.н.с.;

Саганюк Ф. В., к.ю.н., доцент

Центр военно-стратегических исследований Национального университета обороны Украины имени Ивана Черняховского, Киев

Стратегия перехода в условиях гибридной войны к новому формату стратегического руководства сектором безопасности и обороны

Резюме. Статья посвящена проблеме перехода сектора безопасности и обороны Украины и стратегического руководства силами обороны к новому формату функционирования и противодействия российской агрессии.

Ключевые слова: агрессор, гибридная война, сектор безопасности и обороны, силы обороны, стратегическое руководство.

V. Frolov, Ph.D, senior researcher;

F. Sahaniuk, Ph.D, assistant professor

Center for Military and Strategic Studies of the National Defence University of Ukraine named after Ivan Chernyhovsky, Kyiv

Strategy of transition in the conditions of hybrid war to a new format of strategic direction of the security and defense sector of Ukraine

Resume The article is devoted to the problem of the transition of the security and defense sector of Ukraine and the strategic direction of the defense forces to a new format for the functioning and counteraction of Russian aggression.

Keywords: aggressor, hybrid war, security and defense sector, defense, strategic leadership. 